\title{
Striking a Balance between Science and Arts: Mass Media Dilemma in Reporting Health and Environmental Issues
}

\author{
Faridah Ibrahim, PhD, Ali Salman, PhD, Chang Peng Kee, PhD, Normah Mustaffa, PhD \& Fauziah Ahmad, \\ $\mathrm{PhD}$ \\ School of Media and Communication Studies, Faculty of Social Sciences and Humanities \\ Universiti Kebangsaan Malaysia, Malaysia \\ E-mail: fbi@ukm.my; asalmanphd@gmail.com; chang@ukm.my; normahm@ukm.my; zuhair@ukm.my
}

Received: February 23, 2012

Accepted: March 13, $2012 \quad$ Published: April 16, 2012

doi:10.5539/ass.v8n5p77

URL: http://dx.doi.org/10.5539/ass.v8n5p77

This project is funded by the Universiti Kebangsaan Malaysia under the research codes: UKM-SK-05-FRGS0072-2010

\begin{abstract}
Not many people realize that the mass media carry two significant values in their content. One is the value of arts that very much represents the subjective thoughts; and the other is the value of science, which emphasizes precision, accuracy and accountability. Both values reside in the content of the mass media that very much become a precursor and inspiration for government and society to achieve their goals. Nevertheless, both are contradictory in nature. From the general semanticist point of view the words of science could bring objectivity of the mass media to achievable heights. Whilst the words of arts, which are emotion laden yet exhilarating, could lead to human prejudices or perhaps human enlightenment. Although extremely subjective in nature, the arts denote the artistic creation of man that without them, the mass media could hardly persist. On the other hand, news and information of scientific in nature such as pollution, natural catastrophes, diseases and medical discoveries as well as environmental disturbances highlighted by the mass media are seldom being disputed. Hence, based on a content analysis study of four Malaysian mainstream newspapers, this paper will dwell into the plight of the Malaysian print media in trying to create a balance between arts and science especially in communicating health and environmental issues. From a general semantics perspective, the paper will also look at the use and misuse of words by print media practitioners in imparting arts and science messages.
\end{abstract}

Keywords: Precision, Arts, Science, General semantics, Environment

\section{Introduction}

Science and arts writing have been covered by the mass media ever since people learn about news. Today more than ever, people throughout the world are concerned about what the mass media are saying about science and arts. They are concerned about highly technical areas of science and medicine. They want to know why things happen the way they do or what advances in science and technology that can help them have a better quality of life.

At the same time people are also concerned about what is happening around them. Human sufferings due to wars and natural catastrophes, epidemics and pandemics, arm deployment and peace negotiations, war crimes and crimes in the streets such as robberies and thefts, murders, killings and rapes, accidents, earthquakes, volcanic eruptions, landslides and floods, toxic wastes and malpractices, and other environmental problems - all these and others are mixtures of science and arts-oriented news that will always trigger the interests of media audience and readers. Indeed, the mass media, whether local or foreign, will carry both news categories in the content of their on-air news or news columns to attract more readers and audience, which will indirectly attract the advertisers.

But not many people realize that the mass media carry two significant values in their content. One is the value of arts that very much represents the subjective thoughts; and the other is the value of science, which emphasizes precision, accuracy and accountability. Both values exist in the content of the mass media that very much become a forerunner and inspiration for government and society to achieve their goals. Nevertheless, both are 
contradictory in nature. From the general semanticist point of view the words of science could bring objectivity of the mass media to attainable heights (Hayakawa 1979; Mohd Rajib 1984). On the contrary, the words of arts, which are emotion laden yet enlivening, could lead to human prejudices or perhaps human enlightenment.

For instance, environmental problem in a small country like Malaysia, such as haze, always put us in a daze. This is so, when the news takes a human angle, particularly emphasizing on the suffering of people with asthma or other breathing problems. We will be easily angered by irresponsible acts of individuals from neighboring countries who are occasionally causing our country's haze index (in this case Malaysia) to escalate. On the other hand, when the news takes a different turn, showing comparative statistics of haze index across the South East Asian region and Malaysia has the lowest index, we can accept the fact more calmly and will not be too quick in blaming other countries that had caused the haze problem. Such is the case where we can see the difference when a news report is slanted towards arts or science (Ibrahim, 2009).

Although extremely subjective in nature, the arts denote the artistic creation of man that without them, the mass media could hardly persist. On the other hand, news and information which are of scientific in nature such as pollution, natural catastrophes, diseases and medical discoveries as well as environmental disturbances highlighted by the mass media are seldom being disputed.

Hence, based on a content analysis study of four Malaysian mainstream newspapers, this paper will dwell into the plight of the Malaysian print media in trying to create a balance between arts and science especially in communicating health and environmental issues. From a general semantics perspective, the paper will also look at the use and misuse of words by print media practitioners in imparting arts and science messages.

\section{The story of Arts and Science}

Art is a creative activity in the early development of humankind. This creative activity is a subjective quality adhered in human thoughts in their attempt to interpret the world around them. Arts are manifested in artistic works such as hieroglyph, paintings, sculptures, architecture, story-telling, poem and rhyme, speeches, dramas, movies, songs to name a few. Information about arts is not value-free. However, because of language, man can communicate freely and comprehensibly about arts-oriented information.

Science, on the other hand, refers to the system of acquiring knowledge. According to an anthropologist and a Mathematician, Thomas Crump (2001) this system uses observation and experimentation to describe and explain natural phenomenon.

In human communication, humankind uses both elements of science and arts in his language of communication. For instance, in speaking, writing or in imparting knowledge, humankind tends to use some information that is well verified such as mathematics and science. But in media and information warfare strategies, colorful, concocted and distorted information are also imparted for some obvious reasons, for instance to influence and control the mind and heart of others.

Arts, on the other hand, enrich human soul and aspirations. The feeling of "commonness," "togetherness" and "dignity", will depend on how strong humankind hold to the principle of arts, i.e. culture and historical values. Art is often associated with the philosophy of aesthetics as one would observe in the work of arts, films, music, literature and photography.

But, arts and science, are sometimes intertwined in human creativity and activity, and could be perplexing if we attempt to look at the terms separately. Often times we encountered with phrases such as "the art of science", "the art of religion", "the art of philosophising", "the art of warfare", "the art of biology or chemistry or medicine" or even "the art of thinking". Hence, in this study, art denotes something that is value-laden, more personal and sometimes judgmental.

On the other hand, science and technology uses method of verification and no human prejudices, feelings and emotions are involved. In other words, it is a concerted effort by human to understand or to understand better how the natural world works.

\section{Arts and Science in the Media}

Living in a globalised world spearheaded by technological advancement and innovations, humankind has enjoyed a higher level of life expectancy. Food is abundance and disease is subject to varied medical interventions. Environmental concern can be pressing issues but nevertheless, followed by remedial solutions.

At the local and international levels, one can see that societies are exposed to various kinds of sources of information about health matters and environmental issues. Do the media give a comprehensive and fair view of 
issues pertaining to health and environment? Or is the coverage rigged with some slant in favour perhaps, for science-oriented news over arts-oriented news, or vice-versa.

Although there exists a substantial body of research and information analysing the production, nature and influence of media health and environmental messages, studies about the plight of the mass media in balancing the coverage of news on arts and science are lacking. Searle (2002) contends that health research especially has underplayed the role of the media in constructing and influencing illness experience, and in forming expectations of health care. And furthermore, he suggests that research trends under estimate people's use of media for pleasurable experience rather than ascetic messages.

A study by Rahim and Ibrahim (1996) on the coverage of AIDS/HIV by four Malaysian mainstream newspapers found that the issues were treated positively by the newspapers and reporters. Stories on AIDS and HIV/AIDS victims had been reported in a neutral and positive manner, which demonstrated the commitment of the press in handling AIDS problems in a diplomatic and compassionate way.

The study which utilised a content analysis approach also found that the newspapers are careful in writing stories on AIDS; often times news stories paragraphs are short; in simple language and minimum usage of technical and scientific jargons. However, the study recommended that editors and reporters used more visuals, graphics and statistical data that would enhance memory and understanding of readers toward the problem. In a sense-making theory, Dervin (1983) argues that an information that does not meet the needs of the audience in their information seeking will fail to captivate their interest toward the information or messages.

Khor (1994) studied 175 samples of news on AIDS in two Malay mainstream newspapers (Utusan Malaysia and Berita Harian) and two mainstream English dailies (New Straits Times and The Star). The study found that the English daily, The New Straits Times carried the most number of articles on AIDS while Utusan Malaysia carried the least, indicating a lesser interest on AIDS and HIV issues.

While Kilgore (1996) in her study on news reporting on cancers of the female reproductive system in the US newspapers between 1985 and 1993 found the plight of the newspapers to marginalise, moralise and add magic to the coverage. The magical category refers to the reporting of scientific developments in the diagnosis and treatment of cancers which might raise hopes unrealistically with phrases like " dawn of a new era", "pioneering " and "breakthrough".

Bell (1991) found that the preference of news media for events that are recent, factual and conveyed by authoritative sources explained the concentration of news on scientific discoveries and the 'miracle' elements. There is also a preference for stories which are important and having impact on society. Science and arts news do not only deal with health issues. Another significant issue often discussed within these two categories is environmental news. To most people, environment is synonymous with pollution of the air and water. With such a narrow definition, environmental issue becomes so routine and common that it loses its importance and values. Actually environmental news is more than that and has bigger implications. By writing about the environment, the reporters can help promote a broader understanding of ecological sciences and their importance. Besides that, the writings help to show the interrelationships of technical and social knowledge (Ibrahim, 2009).

Environmental news also forms parts of developmental journalism which Gunaratne (1978) described as an integral part of new journalism that involved "analytical interpretation, subtle investigation, constructive criticism and sincere association with the grassroots." While Ogan (1982) identified developmental journalism as the critical examination, evaluation and reporting of the relevance, enactment and impact of development programs by the mass media independent of the government.

Merican (2001:58) quoting Hester and Sukkar argued that "development" broadly defined also includes the "betterment of life" and hence developmental journalist makes a conscious decision that stories written will somehow deal with nation-building and societal development.

While there are many research both local and international that have focused on developmental journalism (see for instance Shah and Gayatri 1994; Griswold and Swenson 1992; Culbertson 1997; Mohamad and Tamam 1996; Murthy 2000; Samiti 2003), there are only a few studies done on environmental reporting.

A content analysis study of environmental news in two Malaysian mainstream newspapers (Utusan Malaysia and New Straits Times) by Faridah Ibrahim (2005) found that there are not many news covered on the environment issues in spite of the fact that it is considered important. Based on interviews with two gatekeepers from the two newspapers, it was found that environmental news actually forms parts of developmental news covered by the newspapers. The study also showed that the English language newspaper tend to cover more environmental news compared to the Malay newspaper. 
Although the Malay newspaper tend to run positive environmental news that bring great advantage to societies, one cannot dismiss the fact that several mainstream papers in Malaysia such as New Straits Times and Utusan Malaysia are instrumental in uncovering several environmental issues over the past years via investigative journalism.

Sarmiti (2003) content analysed 4243 developmental news covered in Utusan Malaysia and New Straits Times in May 2002. Her findings show that issues of development pertaining to economy (16.0 percent) is the most frequently covered by both newspapers, followed by 12.6 percent educational development and 9.5 percent political development. Environmental news category only forms 1.0 percent of developmental news covered by the two mainstream newspapers during the one-month period. The findings showed that both mainstream newspapers do not give much coverage on environmental issues. The situation in Malaysia had not change where environmental news is concerned since just four years before this study was done, Malaysian journalists who had participated in an Environmental Journalism workshop in November 1989 had said that the press coverage of the environment was not only "erratic but superficial".

Murthy (2000) studied issues of development news in four Indian dailies over a period of one year. Based on a content analysis study of these newspapers, about 10 development oriented news emerged from the newspapers' coverage and these include issues on health, education, literacy, communication and transportation, agriculture, industries, housing, population programs, energy and ecology. The last two issues (energy and ecology) can be categorized as environmental issues which are among the popular issues covered by the Indian newspapers.Griswold and Swenson (1993) in their research, "Not in whose backyard? The ethics of reporting environmental issues" looked at four case studies in rural Georgia, United States that focused on the ethical problems which waste disposal and treatment proposals pose for journalists working in rural areas. The cases illustrate the hard choices that journalists face in reporting on environmental issues. Their study found that the media have the potential to play a crucial role in minimising environmental problems but the media in America are not fulfilling that role, partly because of resource shortages and partly because of the ethical orientations traditional to American journalism. Based on their research, they suggest that journalists should view environmental change as a development issue and adopt the global perspective prevalent in environmental ethics as a way to improve environmental issues such as waste disposal planning.

Brosius and Kepplinger (1990) studied the static and dynamic approaches to agenda setting by looking at cross-sectional and longitudinal analyses. They used databases derived from weekly surveys on problem awareness of the public regarding 16 issues and a content analysis of the main German television news shown in 1986. The study reveals no relationship between media coverage and problem awareness under the static analysis. But under dynamic analysis, the findings show that media coverage had caused an increase in problem awareness of four prominent issues in Germany at that time - namely issues of energy supply, defense, environmental protection and European politics. Where issues of environmental protection is concerned, the study indicates that the more coverage of the issues, the higher is the awareness among the German public on the problem attached to the issues.

Chang et al. (2010) researching on the coverage of H1N1 pandemic in Malaysian mainstream newspapers conclude that although framing helps media audience to understand issues better, especially science-oriented issues, it should be emphasized that framing is a mere shortcut to media categorization and easier strategies to describe or explain about an issue. But where issues of life and death are concerned, media practitioners should pay more attention to the use of appropriate frames and appropriate words to describe the frames.

\section{The Study}

A content analysis method, both quantitative and qualitative were used to explore how four Malaysian mainstream newspapers cover health and environmental issues based on arts and science categories and to what extent they prioritise and try to strike a balance between the two categories. The newspapers namely New Straits Times (NST), Utusan Malaysia (UM), Berita Harian (BH) and The Star (TS) were selected based on one-week sampling drawn at random. From the selection, the seven days identified were $17^{\text {th }}$ till $23^{\text {rd }}$ January 2011 . Based on the importance of health and environmental issues to the nation and societies, this study tries to analyse the issue according to the following research questions:

1) How do the newspapers treat arts and science issues pertaining to health and environment?

2) To what extent do the newspapers strike a balance in arts and science reporting?

3) In what way do the headlines reflect sensitivity towards the use and misuse of language? 


\section{Findings and Discussions}

Analysis of science and arts issues from the newspaper samples taken during the period of study showed that the mainstream newspapers have demonstrated a keen interest to balance news and features having scientific and arts elements. The Malay newspapers have more arts -oriented news compared to the science-oriented news coverage in the English language newspapers. Although this line of research has increased our understanding of what connotes arts or science news, it has not address empirically the question of how gatekeepers strike a balance between the two. This would require another study which utilise the in-depth interview techniques on the gatekeepers. Nevertheless, the study demonstrates that the gatekeepers try to have a minimal amount of science-oriented news in their day-to-day coverage. On some days, the study showed that only one or two news are science-oriented news compared to massive arts-oriented news.

The study has managed to take a peak of the arts and science content of the newspapers used as samples in this study. It could be seen that arts-oriented news covered majority of the pages. Science-oriented news are regulars but do not appear in many pages. From the analysis, we can see that readers are exposed to both science and arts news. However, during the period of study there is not much environmental news happenings.

The following headlines provide some interesting arts and science issues covered by the newspapers. Through the headlines, readers are invited to reflect on issues that trigger their interests. Readers are given different array of information, lots of arts and few science- oriented news to digest.

\section{$<$ Insert Table 1 Here $>$}

During the study period, both Malay and English language dailies tend to give more attention to arts-oriented news compared to science-oriented news. There were several interesting issues during the study period that warrant more spaces being given to art-oriented news. One of these being the contention regarding the controversial fifth form secondary school literature textbook, Interlok, alleged to contain some verses that disparage and demoralized the Indian ethnic community in Malaysia. Malaysia being a multi-ethnic and multi-religious society is always careful in reporting ethnic issues. A slight insinuation or innuendo that might demean certain ethnic groups could easily rupture the multi-ethnic social fabric of the country. During this study period, art-oriented news particularly on issues of Interlok and the follow-ups regarding ethnic issues and various communities' responses regarding the issues dominated the news spaces. All the newspapers covered the issues almost every day during this study period.

In terms of science-oriented news, The Star seemed to lead where science-oriented news are concern and science news (Headline: Mental check - School pilot project to detect stress and depression among students, The Star $19^{\text {th }}$ January 2011, page 1) even appeared on its front page indicating the prominence of science-oriented news. The Star also covers a good amount of science-oriented news covering satellites and aerospace issues (Headline: Biggest rocket blasts off with spy satellite TheStar, January $22^{\text {nd }} 2011$, page W40). The Malay language newspapers, Berita Harian and Utusan Malaysia covered a very minimal amount of science-oriented news especially on environmental issues such flood but most of which are rather short and superficial.

Apart from assembling science-oriented news side-by-side with the massive arts-oriented news via news stories, features, opinions and opinion columns, newspapers' editors and reporters are also involved in using languages to spice up their writing. Sometimes the use of adjectives in headlines and news texts are appropriate but sometimes they become misconstrued and hence, inappropriately used. The Malay language dailies are more slanted towards such headlines (for examples: Malaysia's not a tyrant - Indonesian maid Uusan Malaysia, January $17^{\text {th }}$ 2011, page 1; Cabinet orders Interlok dialogue to proceed, Berita Harian, January $21^{\text {st }}$ 2011, page 2 ). "Tyrant" and "orders" are strong judgmental words used in the headlines with negative connotations.

Within the media, news is the primary language genre. Language plays an essential role in news content, be it in broadcast news, online or print. It is often said that people all over the world hear more language from the media than they do directly through human interactions. According to general semanticists such as Alfred Korzybski and his follower, S.I. Hayakawa, language is the source of human misunderstanding because words cannot describe everything about a phenomenon. From their standpoint, words are "maps" and do not reflect the actual "territories". Hence, journalists and editors need to be always mindful of the choice of words used in their news stories, whether in the headlines or the news paragraphs.

How do the four newspapers fair when they need to imply the essence of science and arts in the news stories? Basically with an understanding of general semantics, writers and reporters will be careful in the choice of words in their headlines and news text so that there will be accurateness of meanings. Table 1 shows the adjectives used by the newspapers in their headlines. The words that are shown in bold indicate some inappropriateness in the 
language used. Words like 'arah' or 'orders', 'dumb', indicate arrogance on the part of the speaker (news source), which also reflect the insensitivity of journalists and editors.

Semantically conscious reporters tend to question the appropriateness and accurateness of meanings in their news, and hence are able to minimise judgmental and inferential words which are value-laden and unobjective.

\section{Conclusion}

We have tried in this paper to sort out what is science and arts news from the samples extracted from the four mainstream newspapers over the one-week period selected. Since science and arts are intertwined with one another, the task is nevertheless tedious and challenging. It is indeed a dilemma but with a clear, precise definition of the term "arts" and "science", the task of identification is made easier.

The study demonstrates that media practitioners have developed some kind of specialisation in the process of packaging news that combine the nature of arts and science. Although not many news on health and environment are detected in the samples, nevertheless, the few writings on these areas are written with a "process" in mind rather than a simple linear cause-and-effect. A "process" kind of writing follows a cyclical pattern with elaborations and follow-ups and depths.

\section{References}

Ab. Ghani, M.R. (1984). Semantic analysis of objectivity in two Malaysian newspapers. MA thesis. Univesity of Missouri-Columbia, USA.

Bell, A. (1991). The language of news media. Oxford: Blackwell.

Brosius, H. B. \& Kepplinger, H.M. (1990). The agenda setting function of television news . Static and dynamic news. Communication Research, Vol. 17, No. 2, April, pp. 183-211. http://dx.doi.org/10.1177/009365090017002003

Chang, P.K. Ibrahim, F. \& Mustaffa, M. (2010). Framing a pandemic: Analysis of Malaysian mainstream newspapers in the H1N1 coverage. Journal of Media and Information Warfare, Vol. 3, pp. 105-122.

Crump, T. (2001). Science as seen through the development of scientific instruments. London: Robinson.

Dervin, B. (1983). An overview of sense-making research concept,methods and results to date. Paper presented at the International Communication Association Annual Meeting, Dallas.

D.V.R. Murthy. (2000). Development news coverage in the Indian Press - An analysis of four dailies. Media Asia, Vol. 27, No. 1, pp. 24-53.

Griswold, W.F. \& Swenson, J.D. (1992). Development news in rural Georgia newspapers: A comparison with media in developing nations. Journalism Quarterly, Vol. 69, No. 3, pp. 580-590. http://dx.doi.org/10.1177/107769909206900306

Hayakawa, S.I. (1979). Through the communication barrier. New York: Harper and Row, Publishers.

Ibrahim, F. (2009). Investigator cum scientist in the news industry; A study of environmental reporting. Journal of Media and Information Warfare, Vol. 2, pp. 3-22.

Khor, Y.L. (1994). Ideology and AIDS reporting. Jurnal Komunikasi, Vol. 10, pp. 79-84.

Kilgore, M. (1996). Magic, moralism and marginalisation: Media coverage of cervical, ovarian and uterine cancer. In Parrott, R.I. \& Condir, C.I (Eds), Evaluating women's health messages. New York: Penguin.

Merican, A.M. (2001). The journalist as storyteller. Essays on the scribe and his times. USJ: FAR Publisher.

Mohamad, M. \& Tamam, E. (1996). Rakan kongsi, komunikasi dan media dalam pembangunan (trans: Partners, communication and media in development) Selangor: Penerbit Universiti Pertanian.

Ogan, C.I. (1982). Development journalism: The status of the concept. Gazette, Vol. 29, No. 1-2, pp. 3-13. http://dx.doi.org/10.1177/001654928202900101

Rahim, S.A. \& Ibrahim, F. (1997). Akhbar dan AIDS: Arah dan tujuan (trans: Newspapers and AIDS: Goals and Directions). Paper presented at FSSK Seminar on "Peranan Ilmu Sains Kemasyarakatan dan Kemanusissan dalam masyarakat perindustrian: Menitis arah, organised by the Faculty of Social Sciences and Humanities, UKM 2-3 January 1997.

Sarmiti, N. (2003). Penilaian dan pemilihan berita pembangunan dalam dua akhbar aliran perdana. MA thesis. Universiti Kebangsaan Malaysia. 
Searle, C. (2002). Media and health. London: Sage Publication.

Shah, H. \& Gayatri, G. (1994). Development news in elite and non-elite newspapers in Indonesia. Journalism Quarterly, Vol. 71, No. 2, pp. 411-420. http://dx.doi.org/10.1177/107769909407100214

Table 1. Samples of headlines in the arts and science categories

\begin{tabular}{|c|c|c|}
\hline Newspaper/date & Arts-oriented news & Science-oriented news \\
\hline \multirow[t]{2}{*}{$\begin{array}{l}\text { Berita Harian, } \\
\text { January } 17^{\text {th }} 2011\end{array}$} & $\begin{array}{l}\text { Pilih calon rakyat: PM/Translation: } \\
\text { Choose the people's candidate: PM } \\
\text { (page 1) }\end{array}$ & $\begin{array}{l}\text { No magic cure for waste problems } \\
\text { (page 14) }\end{array}$ \\
\hline & $\begin{array}{l}\text { Kerajaan negeri diingat kurangkan } \\
\text { birokrasi/Translation: State government } \\
\text { being reminded to reduce bureaucracy } \\
\text { (page 7) }\end{array}$ & $\begin{array}{l}\text { Nasmir mampu keluar } 40 \text { juta gelatin } \\
\text { halal sehari/translation: Nasmir is } \\
\text { capable of producing } 40 \text { million halal } \\
\text { gelatine a day (page20) }\end{array}$ \\
\hline \multirow[t]{2}{*}{$\begin{array}{lr}\text { Berita } & \text { Harian } \\
\text { January } & 21^{\text {st }} 2011\end{array}$} & $\begin{array}{l}\text { Kabinet arah dialog Interlok } \\
\text { diteruskan/translation: Cabinet orders } \\
\text { Interlok dialogue to proceed (page 2) }\end{array}$ & - \\
\hline & $\begin{array}{l}\text { Jalan sekolah terbengkalai/translation: } \\
\text { School's road system abandon (page2) }\end{array}$ & - \\
\hline \multirow[t]{3}{*}{$\begin{array}{l}\text { Utusan Malaysia } \\
\text { January } 17^{\text {th }} 2011\end{array}$} & $\begin{array}{l}\text { Calon: Tiada kompromi/translation: } \\
\text { Candidates: No compromising (page 1) }\end{array}$ & $\begin{array}{l}\text { Subsidi ujian mamogram /translation: } \\
\text { Subsidizing of mammogram test } \\
\text { (page 9) }\end{array}$ \\
\hline & $\begin{array}{l}\text { Malaysia tak kejam }- \text { Amah } \\
\text { Indonesia/translation: Malaysia's not a } \\
\text { tyrant - Indonesian maid (page 1) }\end{array}$ & - \\
\hline & $\begin{array}{l}\text { Interlok - mangsa manipulasi/translation: } \\
\text { Interlok -victim of manipulation (page5) }\end{array}$ & - \\
\hline \multirow[t]{5}{*}{$\begin{array}{l}\text { The Star January } \\
22^{\text {nd }} 2011\end{array}$} & Navy rescus (page 1) & $\begin{array}{l}\text { NASA adds slot for Atlantis (page } \\
\text { W40) }\end{array}$ \\
\hline & Grant to spur creativity (page N3) & $\begin{array}{l}\text { Biggest rocket blasts off with spy } \\
\text { satellite (page W40) }\end{array}$ \\
\hline & Voters know what they want (page N6) & $\begin{array}{l}\text { Smartphones give birth to dumb } \\
\text { pedestrians (page W40) }\end{array}$ \\
\hline & $\begin{array}{l}\text { Suu Kyi now has Internet at home (page } \\
\text { W38) }\end{array}$ & $\begin{array}{l}\text { Brazil to create system to prevent } \\
\text { disaster (page W43) }\end{array}$ \\
\hline & Lee predicts PAP fall (page W38) & \\
\hline \multirow[t]{4}{*}{$\begin{array}{l}\text { New Straits Times, } \\
\text { January } 22^{\text {nd }} 2011\end{array}$} & High-seas rescue (page 1) & $\begin{array}{l}\text { Local cars to be fitted with airbags } \\
\text { (page 7) }\end{array}$ \\
\hline & New fund to fuel young ideas (page 3) & $\begin{array}{l}\text { Sarawak floods claim life of } \\
\text { longhouse resident (page13) }\end{array}$ \\
\hline & $\begin{array}{l}\text { Sarawak BN wants concurrent election } \\
\text { (page 4) }\end{array}$ & $\begin{array}{l}\text { Staff, guests give } 30 \text { litres of blood } \\
\text { (page S5) }\end{array}$ \\
\hline & $\begin{array}{l}\text { UPSI students raise RM,812 for victims } \\
\text { (page 1) }\end{array}$ & \\
\hline $\begin{array}{l}\text { The Star January } \\
19^{\text {th }} 2011\end{array}$ & Baby-for-sale racket crippled (page N3) & $\begin{array}{l}\text { Mental check - School pilot project to } \\
\text { detect stress and depression among } \\
\text { students (page 1) }\end{array}$ \\
\hline
\end{tabular}




\begin{tabular}{|c|c|c|}
\hline & $\begin{array}{l}\text { Interlok for Cabinet - Controversial } \\
\text { novel to get attention of higher-ups } \\
\text { (page 10) }\end{array}$ & \\
\hline \multirow[t]{3}{*}{$\begin{array}{l}\text { New Straits Times, } \\
\text { January } 21^{\text {st }} 2011\end{array}$} & BN study on Port Klang issue (page 1) & $\begin{array}{l}2 \text { families flee landslide in the nick of } \\
\text { time (page 14) }\end{array}$ \\
\hline & $\begin{array}{l}\text { PM: Govt fair to all ethnic groups (page } \\
\text { 2) }\end{array}$ & - \\
\hline & $\begin{array}{l}\text { Moves still being made for way out of } \\
\text { Interlok (page 10) }\end{array}$ & - \\
\hline $\begin{array}{l}\text { Utusan Malaysia, } \\
\text { January } 20^{\text {th }} 2011\end{array}$ & $\begin{array}{l}\text { Satu lagi PRK DUN?/translation: } \\
\text { Another by-election for state assembly? }\end{array}$ & $\begin{array}{l}25 \text { jurutera Proton ke Lotus } \\
\text { Renault/translation: } 25 \text { Proton } \\
\text { engineers to train at Renault Lotus } \\
\text { (page 29) }\end{array}$ \\
\hline
\end{tabular}

